Canadian

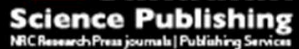

Canadian Journal of Forest Research Revue canadienne de recherche forestière

\title{
Efficient method for rapid multiplication of clean and healthy willow clones via in vitro propagation with broad genotype applicability.
}

\begin{tabular}{|c|c|}
\hline Journal: & Canadian Journal of Forest Research \\
\hline Manuscript ID: & cjfr-2015-0055.R2 \\
\hline Manuscript Type: & Note \\
\hline Date Submitted by the Author: & 22-Jun-2015 \\
\hline Complete List of Authors: & $\begin{array}{l}\text { Palomo-Rios, Elena; Rothamsted Research, Plant Biology \& Crop Science } \\
\text { Macalpine, William; Rothamsted Research, Agroecology } \\
\text { Shield, Ian; Rothamsted Research, Agroecology } \\
\text { Amey, Joanna; Rothamsted Research, Agroecology } \\
\text { Karaoğlu, Cuma; Central Research Institute for Field Crops, } \\
\text { West, Jevon; Rothamsted Research, Plant Biology \& Crop Science } \\
\text { Hanley, Steven; Rothamsted Research, Agroecology } \\
\text { Krygier, Richard; Natural Resources Canada, Canadian Forest Service } \\
\text { Karp, Angela; Rothamsted Research, Agroecology } \\
\text { Jones, Huw; Rothamsted Research, Plant Biology \& Crop Science }\end{array}$ \\
\hline Keyword: & $\begin{array}{l}\text { Salix/willow-breeding, in vitro culture, multiplication, propagation, } \\
\text { phytosanitary }\end{array}$ \\
\hline
\end{tabular}




\section{Rapid in vitro multiplication of disease-free willow clones}

1 Efficient method for rapid multiplication of clean and healthy willow clones via in vitro 2 propagation with broad genotype applicability.

3

4 Elena Palomo-Ríos, William Macalpine, Ian Shield, Jo Amey, Cuma Karaoğlu’, Jevon

5 West, Steven Hanley, Richard Krygier ${ }^{1}$, Angela Karp, Huw D Jones*.

7 Departments of Agroecology and Plant Biology and Crop Science, Rothamsted Research, 8 Harpenden, Herts, AL5 2JQ, UK.

9

${ }^{1}$ Natural Resources Canada, Canadian Forest Service, Edmonton, Alberta, Canada.

$11 *$ Author for correspondence huw.jones@rothamsted.ac.uk

12 Prof. Huw D Jones

Department of Plant Biology and Crop Science

Rothamsted Research

15 Harpenden

16 AL5 3HR

17 UK

+441582938722

${ }^{\dagger}$ Current address: Central Research Institute for Field Crops, 06200 Yenimahalle, Ankara, Turkey. 


\section{Rapid in vitro multiplication of disease-free willow clones}

\section{Abstract}

40 Willow is a versatile crop with considerable potential as a source of renewable biomass for 41 bioenergy. Although breeding new varieties takes less time compared to some other tree 42 species, producing new willow varieties is still a slow and labour-intensive process, partly

43 because clonally propagating the results of each cross is a bottleneck early in the breeding 44 scheme. Here we describe a facile and rapid method for the in vitro culture of a wide range 45 of willow genotypes. We have developed a combination of media and methods for efficient 46 tissue-culture propagation to rapidly multiply individual plants and simultaneously produce 47 clean, stock germplasm applicable to a wide range of willow genotypes that can be 48 phytosanitary-tested to demonstrate their disease-free status. The micro-propagation method 49 described could generate in the order of 5000 viable, transplantable clones from a single plant 50 in just 24 weeks and was used to produce phytosanitary-tested breeding material for export to 51 overcome restriction on the international transport of woody cuttings. This method could 52 represent a valuable biotechnology adjunct to willow breeding programmes and could 53 accommodate early selection via molecular or biochemical markers.

\section{Key Words}

56 Salix/willow-breeding; in vitro culture; multiplication; propagation; phytosanitary. 


\section{Rapid in vitro multiplication of disease-free willow clones}

\section{Introduction}

60 The genus Salix L. (willow) represents a diverse range of over 400 species from the short 61 artic and alpine shrub forms to tall trees including the classic weeping form. Willow species 62 can be found throughout the temperate and arctic regions of the world but some fragmented 63 populations in the high-mountains of central Europe represent relic taxa with significant 64 challenges for conservation (Newsholme 1992). Throughout history willow has been put to 65 many uses including for baskets, cricket bats and as the original source of the analgesic 66 salicin. More recently, there has been significant interest in utilising fast-growing varieties in 67 short-rotation coppice cultivation to fix renewable carbon as a source of bioenergy (Karp and 68 Shield 2008). In common with other highly heterozygous crops that cannot be selfed to form inbred lines, varietal purity in willow is maintained vegetatively by taking woody cuttings. These are usually taken during January and February (when the plants are winter dormant) and can be stored frozen at $-4^{\circ} \mathrm{C}$ for five to six months before planting in spring. An alternative to propagating field-grown material is to use in vitro culture methods to maintain and rapidly multiply willow genotypes or other tree species. Multiplication rates are significantly higher, time-scales shorter, and an additional advantage of axenic in vitro propagation is that it facilitates the removal of plant pathogens found in field-grown material. The risk that these pathogens are present in material for importation is often the cause of import bans by countries that are striving to control the spread of willow diseases. Using phytosanitary-tested tissue cultured willow plants, the authors successfully exported seven different genotypes from the UK to Canada, a country that imposes strict import restrictions on field-grown material, specifically for watermark disease caused by the bacterium Brenneria salicis.

Breeding new willow varieties involves inducing genetic recombination by sexual reproduction followed by at least four rounds of selection and propagation via woody 


\section{Rapid in vitro multiplication of disease-free willow clones}

84

cuttings. Compared to some other trees, willows have numerous advantages for breeding. Closely-related species cross-hybridise readily and produce many seeds; and because plants are dioecious, emasculation is unnecessary. Inflorescence buds are often produced on one year old stems allowing rapid mutigenerational breeding. The genus Salix also contains significant genetic variation for a number of traits of interest providing breeders with an excellent gene pool (Karp et al. 2011). However, although vegetative propagation enables favourable combinations of important traits to be fixed and preserves high levels of heterosis providing hybrid vigour, it can also represent a bottleneck early in the breeding scheme where the necessary clonal multiplication of field-grown material for multi-site testing can be a slow and highly labour-intensive process. To select favourable individuals from each cross, each seed must be germinated and the resultant plants multiplied to give sufficient clones for replicated trials in a range of environments. For instance, the Rothamsted Research willow breeding scheme (Macalpine et al. 2010) requires six years from the initial crosses to reach the multisite yield trialling phase, where 960 individual clones of each breeding line are needed (Fig. S1). An additional outcome of the first years of this process is valuable information for preliminary selection for disease-resistance and vigour. Here we propose a complementary approach where the phenotype selection and multiplication functions of the 'preliminary' and 'observation' trials are partly or completely substituted by tissue-culture to multiply clones which could be incorporated into willow breeding schemes to save four or five years. Explants used previously to initiate direct organogenesis for regeneration in tissue culture include buds, adventitious shoots, and shoot apexes (reviewed in Skalova et al., 2012). Explants are commonly cultured on 'woody plant medium' (WPM) (Lloyd and McCown 1980) or Murashige and Skoog medium (MS) (Murashige and Skoog 1962) supplemented with hormones, sugars and other compounds. However, previous methods developed for particular species proved relatively genotype dependent. Here we outline a 


\section{Rapid in vitro multiplication of disease-free willow clones}

method of tissue-culture propagation to rapidly multiply individual plants and simultaneously produce clean, disease-free stock germplasm using a wide range of genotypes that can satisfy the regulations for cross-border movement.

\section{Materials and methods}

\section{Plant material}

Ten different willow hybrid genotypes were chosen for this study, eight from Rothamstedbred lines RR08153, RR09211, RR09491, RR08402, RR09382, RR09593, RR09411, RR09586, and two from the Rothamsted National Willow Collection (NWC): NWC 674 and NWC 844 (for information on the pedigree of these genotypes see Table S1). One year-old shoots from clones growing in managed fields were collected in January and stored at $-4^{\circ} \mathrm{C}$ until used. Stem sections of $20 \mathrm{~cm}$ were planted in the greenhouse at high humidity and maintained at a day/night temperature of $18 / 14^{\circ} \mathrm{C} \pm 3^{\circ} \mathrm{C}$. Day length was controlled at 16 hours to match day thermo period and ran from 04:00 to 20:00 hrs GMT. Supplementary lighting was provided by 400W SONT lamps. Plants were hand watered until they were $1.5-$ $2 \mathrm{~m}$ tall, when they were used for experimentation.

\section{Sterilization and in vitro cultivation of plant material}

The top $20 \mathrm{~cm}$ of actively-growing shoots with a diameter less than $0.5 \mathrm{~cm}$ were removed from plants in the glasshouse. The apical bud and axillary leaves were carefully removed without damaging the lateral buds and the stem segments were cleaned by first rinsing in $70 \%$ ethanol, then submerging with mild agitation in $25 \%$ bleach (sodium hypochlorite) for $20 \mathrm{~min}$ and washed three times by rinsing in sterile distilled water for $5 \mathrm{~min}$. The lateral buds were removed and placed in distilled water to avoid desiccation. Afterwards, the buds were cleaned of any remaining stem tissue and their protective layers were removed (Fig. 1A). The isolated buds were cultured upright in regeneration media (modified from Song et al. (2006)): 


\section{Rapid in vitro multiplication of disease-free willow clones}

134

135

136

137

138

139

140

141

142

143

144

$1 / 2 \mathrm{MS}$ salts, $1 \mathrm{MS}$ Vitamins, $0.1 \mathrm{mg} \mathrm{L}^{-1}$ indole-3-butyric acid (IBA), $100 \mathrm{mg} \mathrm{L}^{-1}$ myoinositol, $30 \mathrm{~g} \mathrm{~L}^{-1}$ sucrose and $5 \mathrm{~g} \mathrm{~L}^{-1}$ Agargel at $\mathrm{pH} 5.74$, sterilized by autoclaving at $121^{\circ} \mathrm{C}$ for $15 \mathrm{~min}$. In each experiment, 30 buds of each genotype were used, ten buds per petri dish. After one month, the number of buds producing shoots and roots were scored. The growing buds were then transferred to fresh media in magenta pots, five buds per magenta with the same media. The height of growing plants was recorded again after one and a half and three months in magentas. The number of roots per plant was then measured using a rooting index $(0-3)$, calculated as the mean number of primary roots per plant: $0=$ no roots, $1=1-5$ roots, 2 $=5-10$ roots and $3=$ more than 10 roots. This transfer of buds often results in fragile roots becoming damaged or broken. The effect of intentionally removing the existing roots at the first transfer and assessing new root re-growth was studied in the half of buds for each genotype to test if there was any influence in overall growth or rooting capacity.

As an alternative to the relatively labour-intensive method of excising individual buds, short stem sections possessing one or two buds were used as explants (Fig. 1F). Following the same sterilization process, 30 pieces around $2-3 \mathrm{~cm}$ were cut and cultured in the same regeneration medium, five cuttings per magenta. After six weeks of culture, the number of shoots growing for each piece and the length of the stems were recorded, as well as the number of rooting cuttings. The new lateral stems were excised and culture in the same medium.

\section{Multiplication of in vitro micropropagated plant material}

The in vitro multiplication rate was measured experimentally for RR09491 and NWC 844 which were the two genotypes that showed the best response in other in vitro experiments performed. In addition they represent examples from the two sources of germplasm used in this work. 20 cuttings from a single parent plant of each genotype were cultured as described above using the regeneration medium. After six weeks the plants were cut into pieces of $0.5-1$ 


\section{Rapid in vitro multiplication of disease-free willow clones}

cm each containing one to two lateral buds and re-cultured for a further six weeks. This multiplication step was repeated twice more. The height of each plant and the number of new plants obtained were scored.

\section{Acclimatization after transfer to soil at Rothamsted}

Healthy, in vitro-cultured plants with well-developed root systems, were washed with distilled water and transferred to plastic seed trays with 1:1 mixture of peat and perlite. After irrigation with water, they were kept in a grow-box with a transparent lid to maintain high humidity. The lid vents were opened gradually to adapt the plants to ex vitro conditions. After two weeks the plants were removed from the grow-box and a further four weeks they were transferred to larger pots in the glasshouse with a temperature $18 / 14^{\circ} \mathrm{C}$ as described above.

\section{Export and field planting in Canada}

To validate the potential of using micro-propagated willow plants as part of the Rothamsted willow breeding programme, a sample of 49 plants from seven genotypes produced using the isolated bud culture method described above were exported to the Natural Resources Canada, Canadian Forest Service, Edmonton, Alberta, Canada. The Canadian Food Inspection Agency issued a permit (P-2013-00105) for the importation of the willow plantlets subject to their being tested and found free of B. salicis (willow watermark disease). A sample of tissuecultured from each plant was tested by the UK Plant Health Service, Department of the Environment, Food and Rural Affairs. A phytosanitary certification (EC/UK/E\&W/2013/107789) was obtained stating that the plants were free from disease. The plants were rooted in $5 \mathrm{~g} \mathrm{~L}^{-1}$ Agargel in individual $50 \mathrm{ml}$ screw-topped tubes and returned to the growth-room for seven days to recover. The permit requirements being met, the plant containers were secured in an upright position and packaged in padded box for export via express courier to Canada in mid-June 2013. On arrival the plant tubes were allowed to acclimate for 48 hours and were transferred to a commercial peat/vermiculite growth media 


\section{Rapid in vitro multiplication of disease-free willow clones}

184 (Promix ${ }^{\circledR}$ Seed Starting Mix) and watered with distilled water. The pots were placed in a 185 plastic mini-grow chamber with an adjustable top vent, small open side vents and bottom drainage holes. The top vent was gradually opened to adapt the plants to ex vitro conditions. When plants reached the height of the lid (approximately $11 \mathrm{~cm}$ ), they were removed and placed in an open tray on the glasshouse bench. When the plants were approximately $20 \mathrm{~cm}$ tall, they were transplanted into $12 \mathrm{~cm}$ pots. Water soluble $20-20-20$ fertilizer solution $\left(2 \mathrm{~g} \mathrm{~L}^{-}\right.$

${ }^{1}$ Plant-Prod $\left.\AA\right)$ with chelated iron $\left(200 \mathrm{mg} \mathrm{L}^{-1}\right.$ Plant-Prod $\AA$ iron chelate, $\left.13.2 \% \mathrm{Fe}\right)$ to address iron deficiency symptoms was applied to all plants when moved from the growth chamber. All the plants were moved out of the glasshouse to an open storage area in late August 2013 and fertilized with 8-30-20 water-soluble fertilizer (3.1 g L ${ }^{-1}$ Plant-Prod $\left.®\right)$ and iron chelate as above. The plants were transplanted to weed free tilled beds in late September.

\section{Results}

In vitro cultivation of isolated axillary buds

After one month of culture in the regeneration medium, the majority of isolated buds had formed stem and leaf tissues and a large number of them had also formed roots (Figs. 1B-C \& 2A). Most of the ten genotypes showed a very high, or $100 \%$, shooting response, but in one genotype, RR09586, the percentage of shooting buds was low (13.3\%). The overall percentage of buds that formed roots was lower compared to those forming shoots. In one of the genotypes, RR09382, no buds rooted at all during this first month of culture, despite $90 \%$ of them having good shoots. Only in two genotypes, RR09491 and RR09411, did 100\% of buds produce shoots and roots. After transferring the developing plants to fresh regeneration medium in magentas pots for a further 1.5 months of culture, buds of five of the ten genotypes reached $100 \%$ shooting and rooting (Fig. 2B). The percentage of rooting buds 


\section{Rapid in vitro multiplication of disease-free willow clones}

209 also greatly increased its shooting whilst in genotype RR09382 the shooting percentage decreased dramatically, owing to the death of a high number of buds, which did not root. In this latter genotype, only the few shooting buds that eventually formed roots survived (Fig. 2B). The general morphology of the bud-derived plants varied from genotype to genotype (Fig. 1B-C). In most genotypes, the mean stem length ranged between 1.0-2.5 cm; however, three of the genotypes (RR09491, RR08402 and NWC 844) had significantly longer stems of 4.5-6 cm. When plants were two and a half months old, they were transferred again to fresh regeneration medium in magentas and cultured for an additional one and a half months (Fig. S2). Apart from RR09382, RR09593 and RR09411, all genotypes showed good root development. Very high numbers of roots, typically at least ten (shown by rooting index 3), were found in three genotypes (Fig. S2).

\section{Effect of root excision on shoot establishment in new media}

The classical approach for transferring plant cultures to fresh media is to clean and retain as much of the root structure as possible. However, this process is labour intensive and experience has shown that willow stems readily produce new roots from cut stems. Thus we investigated the effect of cutting the stem just above the media surface and scored the rerooting potential of these cut stems in fresh media. Most of the genotypes tested showed no (or only a small) difference in subsequent establishment and growth between cutting/reinitiating new roots and transferring the roots intact. Although not statistically significant, it was interesting that one genotype, RR09586, had a slightly better mean rooting and shooting response after root excision. Cutting the stems prior to transfer made planthandling much quicker, so this method was used subsequently for all routine transfers.

\section{In vitro cultivation of nodal segments}

232 The isolation and culture of axillary buds requires the use of a dissecting microscope and is a 233 relatively laborious process. As an alternative, we investigated a methodology utilising 


\section{Rapid in vitro multiplication of disease-free willow clones}

234

235

236

237

238

239

240

241

242

243

244

245

246

247

248

249

250

251

252

253

254

255

256

257

segments of stems each possessing one or two lateral buds, after one and a half months of culture, new roots and lateral shoots grew from almost all of the nodal segments cultured (Fig. 1G \& 3A). Only in one genotype, RR09593, did the rooting/shooting response drop to less than $90 \%$. In the case of nodal segments possessing two buds, usually both of them formed new lateral shoots and these could in turn be rooted to form independent plants. Furthermore, after one and a half months of culture the length of the new axillary shoots formed from nodal stems was greater than those from isolated buds after their first culture period (Fig. 3B). Using the isolated bud culture, shoots took an additional one and a half to three months of culture to obtain the same length as shoots from nodal segments (data not shown). In summary, the use of nodal stem segments produced more and larger plants in less time and with less effort than the isolated buds culture approach. Despite these advantages, we observed (but did not quantify) that the cultures of isolated bud resulted in lower contamination levels compared with the nodal segment culture and that this differential was more pronounced with field-collected material compared with glasshouse grown plants.

\section{Optimisation and measurement of in vitro multiplication rates}

Several parameters thought to influence the multiplication rate of in vitro grown willow plants were investigated. For these experiments we focused on genotypes RR09491 and NWC 844 which had consistently good shooting, rooting and growth response in culture but data from other in vitro experiments lead us to expect that other genotypes would show broadly similar responses. By far the best method to improve the multiplication rate was to take plants after a culture period and cut the stem into several small pieces each with only one bud, or two when the distance between buds was very small (Fig. 1I). We observed that if these pieces of stems kept their leaves, the stem sections rooted and the lateral buds grew in a shorter time. 


\section{Rapid in vitro multiplication of disease-free willow clones}

258

259

260

261

262

263

264

265

266

267

268

269

270

271

272

273

274

275

276

277

278

279

280

281

282

Although NWC 844 consistently grew faster than RR09491, the height of the new plants obtained in each round of multiplication remained relatively consistent for each genotype (Table 1). For both genotypes the number of cuttings that could be taken at each multiplication step was dependent on the number of lateral buds. In 24 weeks a total of 5,879 and 1,810 clonal plants could be obtained from a single plant of NWC 844 and RR09491 respectively using only 20 cuttings from each original parent. These multiplication steps can be continued or more cuttings could be taken from the original parent plant if more clones are required.

\section{Acclimatisation in glasshouse then transfer to field}

In vitro plants of all genotypes were transferred to soil in the glasshouses at Rothamsted Research UK, whilst the seven genotypes exported to Canada were transferred first to an organic medium under glass and then into the field. At Rothamsted, all ten of the genotypes were successfully transferred in this way. Only one genotype (RR8153) possessed a relatively low success rate with only $25 \%$ and $33 \%$ surviving from nodal segments and isolated buds cultures respectively, possibly owing to the small size of the plants transferred. After hardening-off, they can then be either transferred to the field as a whole plant (after the risk of frost has passed) or allowed to grow under glasshouse conditions before conventional woody stem cuttings are taken and field-planted (data not shown). Transportation and field establishment of plants in Edmonton Canada was also successful with low mortality of plants during transport (of the 49 plants shipped only one died). However, many of the plants lost leaves either in the tubes during shipping or during the transfer to organic growing media and some also displayed chlorotic symptoms (Table S2). Despite this, almost all the plants recovered by producing new leaves from buds located in the leaf axils either by the time of transfer to organic growing media or immediately afterwards. Iron deficiency became a serious issue after the plants were removed from the mini-grow chamber and placed on the 


\section{Rapid in vitro multiplication of disease-free willow clones}

283

glasshouse bench. Chelated iron applied both during irrigation and as a foliar spray mitigated the deficiency. Iron deficiency symptoms were not observed in the field. It is likely that leafloss and iron deficiency were exacerbated by the prolonged time in a relatively small volume of the same media and the period of 56 hours darkness the plants experienced during transportation. Future transfers will be managed in a different way to mitigate these negative effects.

\section{Discussion}

Plant breeding is a resource-intensive process and any steps that can increase efficiency and reduce the number of years in breeding programmes impact greatly by reducing costs and increasing success rates. This is particularly the case in species with long production and generation cycles, such as trees. To improve the efficiency of breeding biomass willows we successfully developed an efficient method of multiplying disease-free genotypes via in vitro propagation. The in vitro growth of 10 different genotypes, including hybrids of S. purpurea, S. viminalis, S. schwerinii, S. dasyclados, S. triandra, S. rossica, S. caprea and S. cinerea, chosen from the Rothamsted National Willow Collection and breeding trials were tested. Others groups have previously studied in vitro micro-propagation of Salix spp and found a strong genotype effect (Bergman et al. 1985; Liesebach and Naujoks 2004; Lyyra et al. 2006; Mashkina et al. 2010). We also observed some differences in tissue-culture response and growth parameters of different genotypes, but we could obtain plants from every tested genotype using the same culture medium. Only one genotype, RR09382, showed a low shoot formation using isolated bud culture; however, the culture response was normal using nodal segments as explants. This shows that for some sensitive genotypes, the culture of nodal segments is more appropriate than the isolated bud culture; possibly, because it is a less stressful culture method which maintains some mother-tissue during the early phase of the 


\section{Rapid in vitro multiplication of disease-free willow clones}

308

309

310

311

312

313

314

315

316

317

318

319

320

321

322

323

324

325

326

327

328

329

330

331

332

buds' growth. In previous reports, depending on the genotypes studied, it proved necessary to use cytokines to obtain the regeneration of new shoots from axillary buds. The most frequently used cytokine was 6-Benzylaminopurine (BAP) (Bergman et al. 1985; Mashkina et al. 2010; Park et al. 2008; Skalova et al. 2012), but also thidiazuron (TDZ) was used for shoot induction with S. tetrasperma (Khan and Anis 2012). For propagation of S. caprea, the most suitable was reported to be a hormone-free medium combined with the use of active charcoal (Liesebach and Naujoks 2004; Naujoks 2007). We also observed good shoot formation in the absence of cytokinin, but we found it necessary to use the auxin IBA to facilitate root development. Although spontaneous in vitro rooting of some willow cultivars has been described (Khan et al. 2011; Lyyra et al. 2006; Park et al. 2008), more commonly, rooting has been induced by the inclusion of some auxin like IAA (Mashkina et al. 2010), NAA (Bergman et al. 1985), or in most cases, IBA (Khan et al. 2011; Khan and Anis 2012; Naujoks 2007; Park et al. 2008; Skalova et al. 2012). In this paper, we reported the use of a simple, single medium, $1 / 2$ MS with $0.1 \mathrm{mg} \mathrm{L}^{-1} \mathrm{IBA}$, which was successful in a wide range of genotypes for every culture stage: shoot induction, elongation, multiplication and rooting of in vitro willow plants. As expected, we observed that stem growth was much better after a plant had developed a good root system; although the presence of roots was not essential for shoot induction. Mashkina et al. (2010) also observed a relationship between low rooting capacity and moderate growth of in vitro willow plants. It seems, in some genotypes, that root growth may be a prerequisite for shoot elongation, or at least has some positive influence on it, as we have observed.

Fungal and bacterial contamination is a frequently reported problem for in vitro multiplication of willow plants (Liesebach and Naujoks 2004; Mashkina et al. 2010; Skalova et al. 2012). To avoid contamination problems, we used a relatively aggressive sterilization method, with high bleach percentage (25\%), resulting in very low or zero contamination 


\section{Rapid in vitro multiplication of disease-free willow clones}

333

rates. We found that this method did not have any negative effect on the axillary bud growth. We also observed less contamination when cuttings for in vitro culture were taken from glasshouse-grown donor plants rather than field-grown material. Moreover, we observed lower contamination rate of explants when we culture isolated buds in comparison with the nodal segments culture; therefore, the isolated bud culture is more suitable for material with high contamination risk.

The experiment to investigate the multiplication rates in genotypes RR09491 and NWC 844 plants revealed that the first culture step consistently gave more axillary bud growth from which to take lateral shoots for multiplication. The multiplication rate in subsequent culture steps was lower and tended to reach a stable number, independently of plant height, at the second or third culture step. Bergman et al. (1985) also observed changes in the number of new culturable pieces from in vitro willow plants. They suggested that it is necessary to observe the regeneration in several subsequent subcultures to determine the multiplication in vitro rate of each genotype; an observation that we support. Using the data obtained in this multiplication trial and assuming the number of culturable new shoots per plant stabilised after the third culture step, we conclude that more than 6,000 plants from NWC 844 genotype and 2,000 from RR09491 can be generated after 6 months of multiplication culture starting with only 20 cuttings obtained from one glasshouse-grown plant. The transfer of plants from tissue culture to soil was not a restrictive step, with a high percentage of success in all genotypes tested. Additionally, we demonstrated for the first time that these tissue-culture plants could be exported and successfully transferred to the field under challenging low-temperature conditions. If this in vitro multiplication process was incorporated into the early phase of the traditional Rothamsted breeding scheme, we propose it could save around four to five years by significantly reducing the time required to generate the number of plants needed to carry out the multisite yield test (Fig. S1). It may also be able 


\section{Rapid in vitro multiplication of disease-free willow clones}

358

359

360

361

362

363

364

365

366

367

368

369

370

371

372

373

374

375

376

377

378

379

380

381

382

383

384

385

386

387

388

to adapt this protocol to enable the micro-propagation in soilless compost which could save some costs of sterile tissue culture. However, in our experience, each round of propagation would take longer to achieve the same results. Multiplication of promising clones selected immediately after crossing using DNA marker analysis could then be done more rapidly using these micro-propagation methods.

\section{Acknowledgements}

This work was supported by the UK Biotechnological and Biological Sciences Research Council (BBSRC) “Cropping Carbon” Institute Strategic Programme Grant at Rothamsted Research [grant number BB/I014934/1]. Rothamsted Research is an Institute supported by the BBSRC.

\section{References}

Bergman, L., Vonarnold, S., and Eriksson, T. 1985. Genotypic differences between 5 willow clones cultured in vitro on media of different benzyladenine concentration. Physiol. Plant. 64(2): A12-A12.

Karp, A., Hanley, S.J., Trybush, S.O., Macalpine, W., Pei, M., and Shield, I. 2011. Genetic Improvement of Willow for Bioenergy and Biofuels. Free Access. J. Integr. Plant Biol. 53(2): 151-165. doi: 10.1111/j.1744-7909.2010.01015.x.

Karp, A., and Shield, I. 2008. Bioenergy from plants and the sustainable yield challenge. New Phytol. 179(1): 15-32. doi: 10.1111/j.1469-8137.2008.02432.x.

Khan, M., Ahmad, N., and Anis, M. 2011. The role of cytokinins on in vitro shoot production in Salix tetrasperma Roxb.: a tree of ecological importance. Trees 25(4): 577-584. doi: 10.1007/s00468-0100534-6.

Khan, M., and Anis, M. 2012. Modulation of in vitro morphogenesis in nodal segments of Salix tetrasperma Roxb. through the use of TDZ, different media types and culture regimes. Agrofor. Syst. 86(1): 95-103. doi: 10.1007/s10457-012-9512-x.

Liesebach, M., and Naujoks, G. 2004. Approaches on vegetative propagation of difficult-to-root Salix caprea. Plant Cell Tissue Organ Cult. 79(2): 239-247. doi: 10.1007/s11240-004-0665-9.

Lloyd, G., and McCown, B. 1980. Use of microculture for production and improvement of Rhododendron spp. In HortScience. Amer Soc Horticultural Science 701 North Saint Asaph Street, Alexandria, Va 22314-1998. pp. 416-417. 


\section{Rapid in vitro multiplication of disease-free willow clones}

Lyyra, S., Lima, A., and Merkle, S.A. 2006. In vitro regeneration of Salix nigra from adventitious shoots. Tree Physiol. 26(7): 969-975.

Macalpine, W., Shield, I., and Karp, A. 2010. Seed to near market variety; the BEGIN willow breeding pipeline 2003-2010 and beyond. In BIOTEN Conference Proceedings, Birmingham, UK.

Mashkina, O.S., Tabatskaya, T.M., Gorobets, A.I., and Shestibratov, K.A. 2010. Method of clonal micropropagation of different willow species and hybrids. Appl. Biochem. Microbiol. 46(8): 769-775. doi: 10.1134/s0003683810080065.

Murashige, T., and Skoog, F. 1962. A revised medium for rapid growth and bio assays with tobacco tissue cultures. Physiol. Plant. 15(3): 473-497. doi: 10.1111/j.1399-3054.1962.tb08052.x.

Naujoks, G. 2007. Micropropagation of Salix caprea L. In Protocols for Micropropagation of Woody Trees and Fruits. Edited by S.M. Jain and H. Häggman. Springer Netherlands. pp. 213-220.

Newsholme, C. 1992. Willows: the genus Salix. Timber Press, Inc., Portland, Oregon.

Park, S.Y., Kim, Y.W., Moon, H.K., Murthy, H.N., Choi, Y.H., and Cho, H.M. 2008. Micropropagation of Salix pseudolasiogyne from nodal explants. Plant Cell Tissue Organ Cult. 93(3): 341-346. doi: 10.1007/s11240-008-9362-4.

Skalova, D., Navratilova, B., Richterova, L., Knitl, M., Sochor, M., and Vasut, R.J. 2012. Biotechnological methods of in vitro propagation in willows (Salix spp.). Cent. Eur. J. Biol. 7(5): 931940. doi: 10.2478/s11535-012-0069-5.

Song, J., Lu, S., Chen, Z.-Z., Lourenco, R., and Chiang, V.L. 2006. Genetic transformation of Populus trichocarpa genotype Nisqually-1: A functional genomic tool for woody plants. Plant Cell Physiol. 47(11): 1582-1589. doi: 10.1093/pcp/pcl018. 


\section{Rapid in vitro multiplication of disease-free willow clones}

415 Table 1: Number and length of RR09491 and NWC 844 cuttings used in each round of nodal 416 segment multiplication culture.

417

\begin{tabular}{ccccccc}
\hline & $\begin{array}{c}\mathbf{1}^{\text {st }} \text { multiplication culture } \\
\text { at } \mathbf{6} \text { weeks }\end{array}$ & $\begin{array}{c}\mathbf{2}^{\text {nd }} \text { multiplication } \\
\text { culture } \\
\text { at 12 weeks }\end{array}$ & \multicolumn{2}{c}{$\begin{array}{c}\mathbf{3}^{\text {rd }} \text { multiplication } \\
\text { culture } \\
\text { at 18 weeks }\end{array}$} \\
\cline { 2 - 7 } SEGMENTS & $\begin{array}{c}\text { Length } \\
\text { (cm) }\end{array}$ & $\begin{array}{c}\text { Number } \\
\text { of cuttings }\end{array}$ & $\begin{array}{c}\text { Length } \\
\text { (cm) }\end{array}$ & $\begin{array}{c}\text { Number } \\
\text { of cuttings }\end{array}$ & $\begin{array}{c}\text { Length } \\
\text { (cm) }\end{array}$ & $\begin{array}{c}\text { Number } \\
\text { of } \\
\text { cuttings }\end{array}$ \\
\hline RR09491 & $2.56 \pm 0.81$ & $5.75 \pm 1.52$ & $2.26 \pm 1.17$ & $3.95 \pm 1.97$ & $3.46 \pm 1.27$ & $3.90 \pm 1.4$ \\
\hline NWC 844 & $5.82 \pm 1.7$ & $9.45 \pm 1.85$ & $6 \pm 2.36$ & $6.44 \pm 2.53$ & $6 \pm 2.27$ & $4.83 \pm 1.51$ \\
\hline
\end{tabular}

418 For each genotype, 20 cuttings were put through three rounds of multiplication. Data 419 represents means $\pm \mathrm{SE}$.

420

421 


\section{Rapid in vitro multiplication of disease-free willow clones}

422 Figure 1: In vitro cultivation of isolated axillary buds and nodal segments. A: Isolation and

423 culture of lateral buds in regeneration medium. B-C: New shoots obtained from buds cultured

424 for 1 month B is NWC 674, C is RR09491. D: Plants obtained from buds after 2.5 months. E:

425 Plants obtained from buds after 4 months. F: Initial nodal segment culture (pieces of stems

426 with 1-2 lateral buds) in regeneration medium. G: New shoots obtained from buds growing in

427 the nodal segments after 1 months of culture. H: Plants obtained from nodal segments after

428 cutting the new shoots formed and culture for additional 1.5 months. I: Optimisation of in

429 vitro multiplication by cutting each plant into several pieces, each one with 1-2 lateral buds

430 and culture of these pieces after approximately 10 days after they were cut and after 6 weeks

431 of culture. All bars $=1 \mathrm{~cm}$.

432

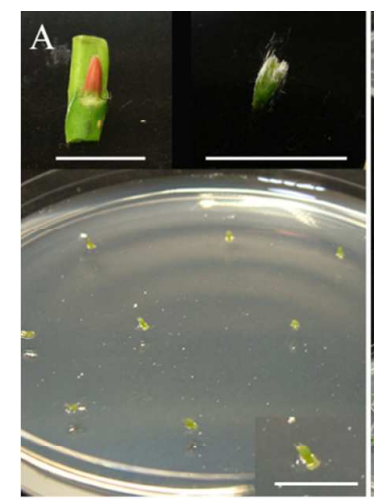

$\mathrm{F}$
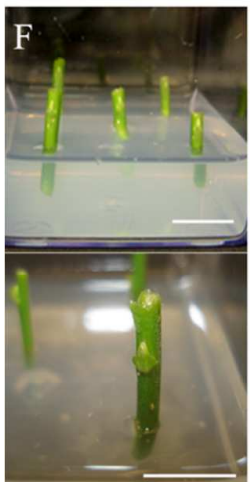

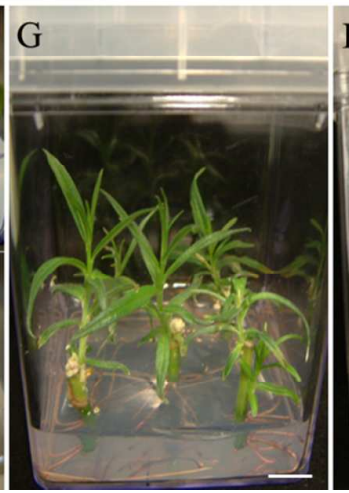

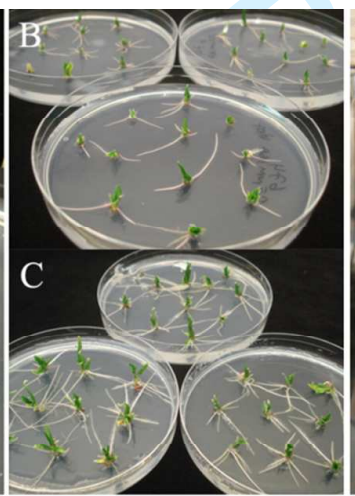

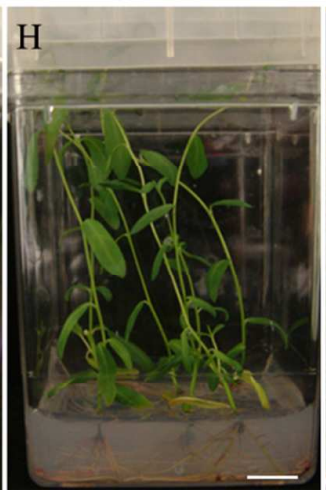

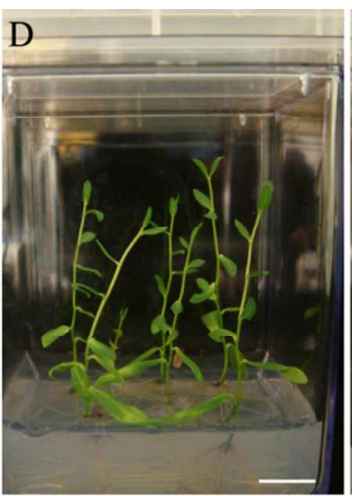
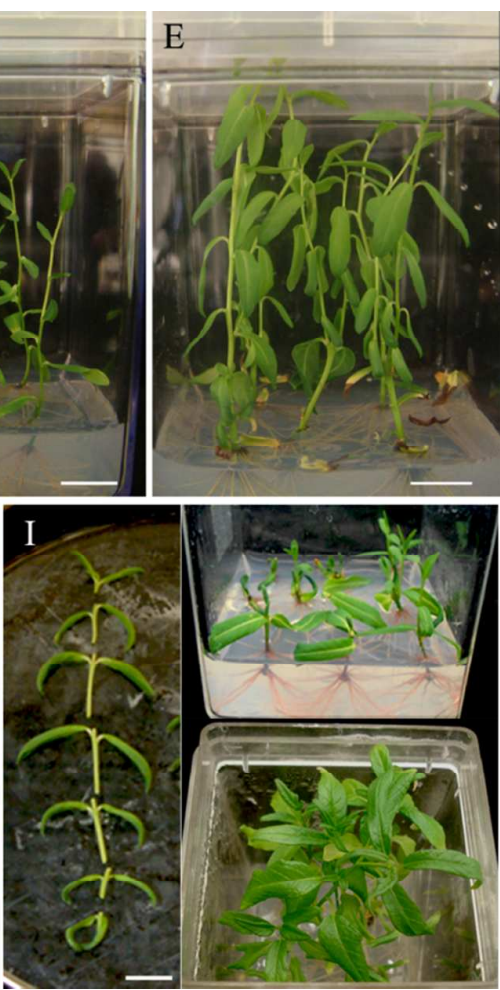


\section{Rapid in vitro multiplication of disease-free willow clones}

437

438

439

440

Figure 2: Percentage of shooting and rooting buds from ten different genotypes of willow. A: After 1 month of culture. B: After their transfer to magentas for an additional 1.5 month of culture in fresh regeneration medium. Data represents means $\pm \mathrm{SE}$.

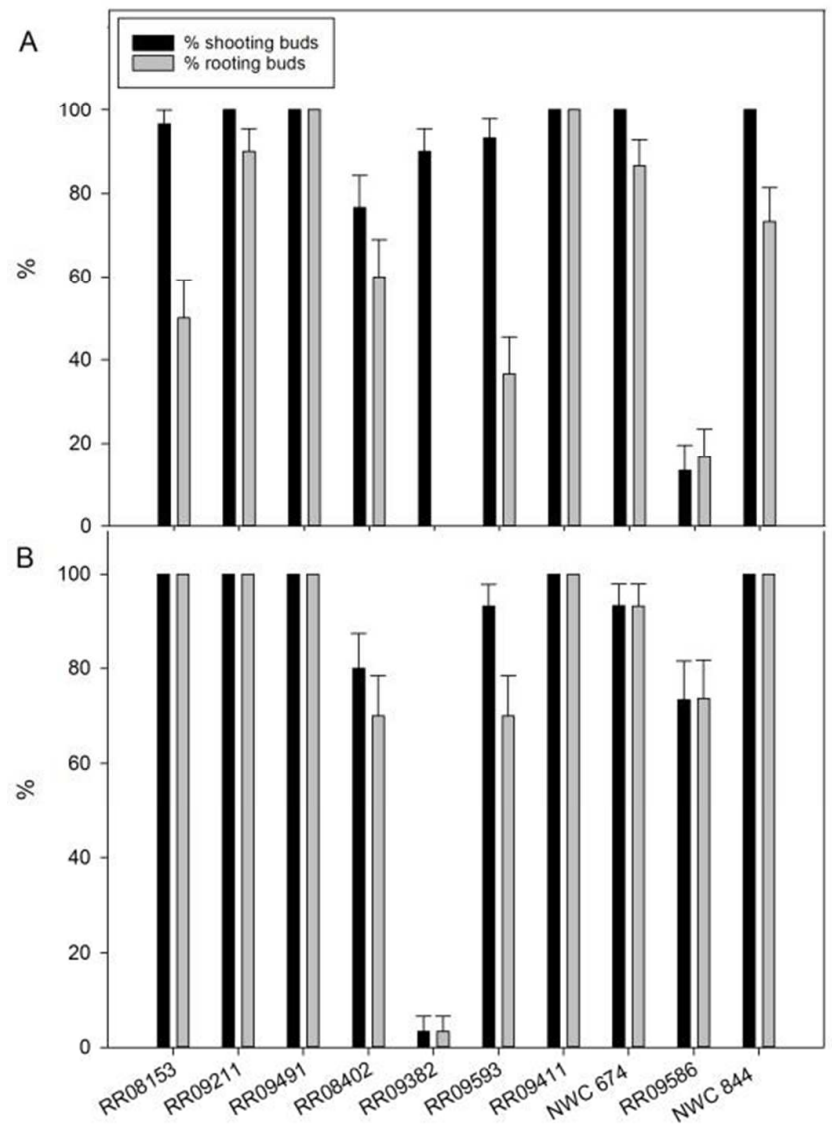




\section{Rapid in vitro multiplication of disease-free willow clones}

442 Figure 3: A: Shooting and rooting response of nodal segments from 10 different genotypes

443 cultured for 1.5 months in regeneration medium in magentas. B: Length in $\mathrm{cm}$ (mean $\pm \mathrm{SE}$ )

444 of the new axillary shoots obtained after 1 and 1.5 months of culture in regeneration medium

445 of isolated buds and nodal segments respectively.

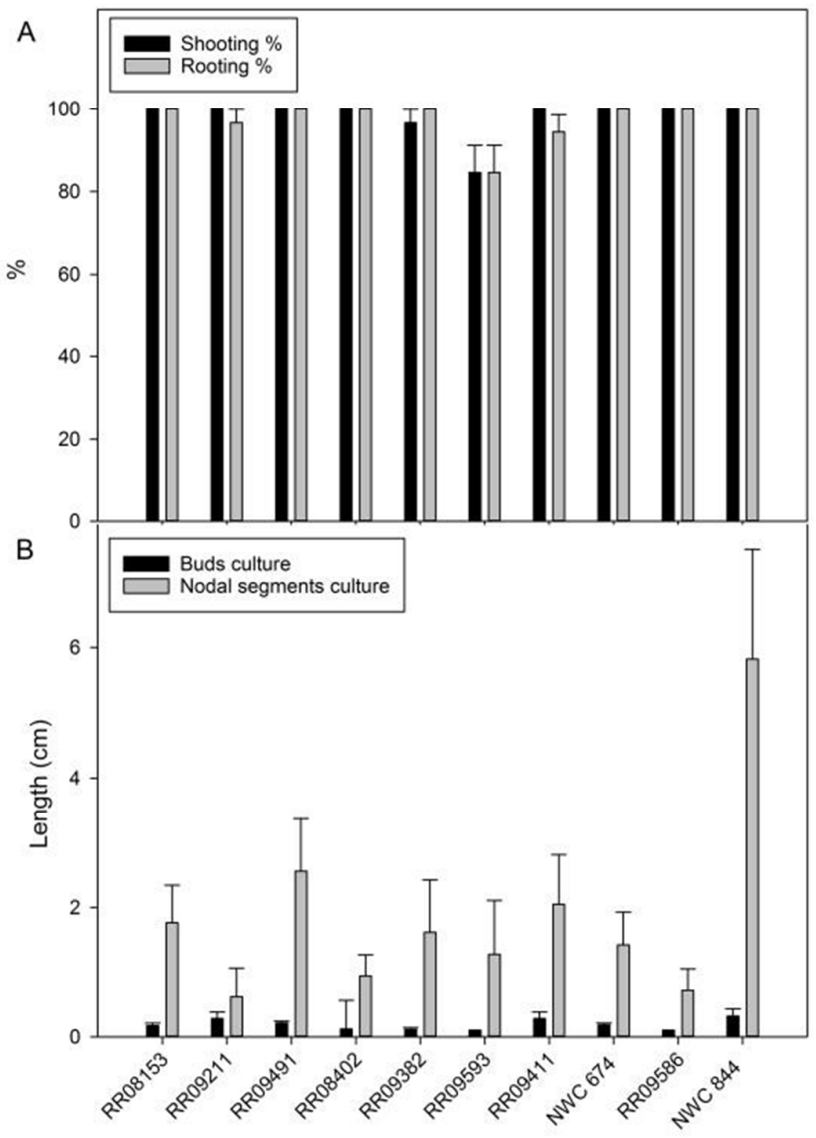


Table S1: Pedigree of genotypes used in tissue culture experiments.

\begin{tabular}{|c|c|c|c|c|c|c|}
\hline $\begin{array}{l}\text { Cultivar/ } \\
\text { Breeding } \\
\text { Line }\end{array}$ & † Parent & $\widehat{\partial}$ Parent & $\begin{array}{c}\stackrel{+}{,} \stackrel{+}{ } \\
\text { Grandparent }\end{array}$ & $\begin{array}{c}\hat{\partial}, \stackrel{+}{ } \\
\text { Grandparent }\end{array}$ & $\begin{array}{c}\stackrel{9}{ },{ }^{\lambda} \\
\text { Grandparent }\end{array}$ & $\begin{array}{c}\hat{0}, \hat{0} \\
\text { Grandparent }\end{array}$ \\
\hline RR09211 & 'Tordis' & 'Sven' & $\begin{array}{c}\text { (S. schwerinii } \\
\text { 'L79069') } \times((S \text {. } \\
\text { viminalis } \\
\text { 'L78195' } \times S \text {. } \\
\text { viminalis } \\
\text { 'L78101') } \\
\text { 'Orm') } \\
\text { 'Tora' }\end{array}$ & $\begin{array}{l}\text { (S. viminalis } \\
\text { 'L78195' } \times \text { S. } \\
\text { viminalis } \\
\text { 'L78101') } \\
\text { 'Orm' }\end{array}$ & $\begin{array}{l}\text { (S. viminalis } \\
\text { 'N81102’ } \times \text { S. } \\
\text { viminalis } \\
\text { 'L830201') } \\
\text { 'Jorunn' }\end{array}$ & $\begin{array}{c}(\text { S. schwerinii } \\
\text { 'L79069') } \times \\
((\text { S. viminalis } \\
\text { 'L78195' } \times \text { S. } \\
\text { viminalis } \\
\text { 'L78101') } \\
\text { 'Orm') } \\
\text { 'Bjorn' }\end{array}$ \\
\hline RR08155 & 'Tora' & $\begin{array}{l}\text { S. caprea } \times \\
\text { S. cinerea } \times \\
\text { S. viminalis }) \\
\text { 'Grandis' }\end{array}$ & $\begin{array}{l}\text { S. schwerinii } \\
\text { 'L79069' }\end{array}$ & $\begin{array}{l}\text { (S. viminalis } \\
\text { 'L78195' } \times \text { S. } \\
\text { viminalis } \\
\text { 'L78101') } \\
\text { 'Orm' }\end{array}$ & - & - \\
\hline RR09491 & RR05196 & $\begin{array}{c}S . \\
\text { dasyclados } \\
\text { '77056' }\end{array}$ & $\begin{array}{c}\text { (S. triandra } \\
\text { 'SW911066' } \times S . \\
\text { viminalis } \\
\text { 'L81102') } \times((S . \\
\text { viminalis } \\
\text { 'L78198' } \times S . \\
\text { viminalis } \\
\text { 'L81092') 'Jorr') } \\
\text { 'Inger' }\end{array}$ & $\begin{array}{c}((\text { S. viminalis } \\
\text { 'Pavainen') } \times \\
((\text { S. viminalis } \\
\text { 'L78195' } \times S \text {. } \\
\text { viminalis } \\
\text { 'L78101') } \\
\text { 'Orm') } \\
\text { 'Bjorn') } \\
\text { 'Quest' }\end{array}$ & - & - \\
\hline RR08402 & SW930812 & $\begin{array}{c}S . \\
\text { dasyclados } \\
\text { 'Loden' }\end{array}$ & $\begin{array}{c}\text { (S. viminalis } \\
\text { 'N81102' } \times \text { S. } \\
\text { viminalis } \\
\text { 'L830201') } \\
\text { 'Jorunn' }\end{array}$ & $\begin{array}{c}\text { (S. schwerinii } \\
\text { 'L79069') } \times \\
((\text { S. viminalis } \\
\text { 'L78195' } \times S \text {. } \\
\text { viminalis } \\
\text { 'L78101') } \\
\text { 'Orm') } \\
\text { 'Bjorn' }\end{array}$ & - & - \\
\hline RR09382 & 'Tora' & $\begin{array}{c}S . \\
\text { dasyclados } \\
\text { 'Loden' }\end{array}$ & $\begin{array}{l}\text { S. schwerinii } \\
\text { 'L79069' }\end{array}$ & $\begin{array}{l}\text { (S. viminalis } \\
\text { 'L78195' } \times \text { S. } \\
\text { viminalis } \\
\text { 'L78101') } \\
\text { 'Orm' }\end{array}$ & - & - \\
\hline RR09593 & RR05337 & 'Quest' & $\begin{array}{l}\text { S. dasyclados } \\
\text { 'Aud' }\end{array}$ & S. rossica & $\begin{array}{l}\text { S. viminalis } \\
\text { 'Pavainen' }\end{array}$ & $\begin{array}{c}\text { (S. schwerinii } \\
\text { 'L79069') } \\
((\text { S. viminalis } \\
\text { 'L78195' } \times \text { S. } \\
\text { viminalis } \\
\text { 'L78101') } \\
\text { 'Orm') } \\
\text { 'Bjorn' }\end{array}$ \\
\hline
\end{tabular}




\begin{tabular}{|c|c|c|c|c|c|c|}
\hline RR09411 & $\begin{array}{c}\text { 'Roth } \\
\text { Chiltern' }\end{array}$ & 'Olof' & $\begin{array}{c}\text { (S. schwerinii } \\
\text { 'K3 Hilliers' } \times \\
((\text { S. viminalis } \\
\text { 'L78195' } \times \text { S. } \\
\text { viminalis } \\
\text { 'L78101') } \\
\text { 'Orm') 'Bjorn') } \\
\text { 'Discovery' }\end{array}$ & $\begin{array}{c}((S . \text { viminalis } \\
\text { 'Pavainen') } \times \\
((\text { S. viminalis } \\
\text { 'L78195' } \times \text { S. } \\
\text { viminalis } \\
\text { 'L78101') } \\
\text { 'Orm') } \\
\text { 'Bjorn') } \\
\text { 'Quest' }\end{array}$ & $\begin{array}{l}\text { S. viminalis } \\
\text { 'Bowles } \\
\text { Hybrid' }\end{array}$ & $\begin{array}{c}(\text { S. schwerinii } \\
\text { 'L79069') } \times \\
((\text { S. viminalis } \\
\text { 'L78195' } \times \text { S. } \\
\text { viminalis } \\
\text { 'L78101') } \\
\text { 'Orm') } \\
\text { 'Bjorn' }\end{array}$ \\
\hline RR09586 & 'Tordis' & RR04259 & $\begin{array}{c}\text { (S. schwerinii } \\
\text { 'L79069') } \times((S \text {. } \\
\text { viminalis } \\
\text { 'L78195' } \times S \text {. } \\
\text { viminalis } \\
\text { 'L78101') } \\
\text { 'Orm') } \\
\text { 'Tora' }\end{array}$ & $\begin{array}{l}\text { (S. viminalis } \\
\text { 'L78195' } \times \text { S. } \\
\text { viminalis } \\
\text { 'L78101') } \\
\text { 'Orm' }\end{array}$ & $\begin{array}{l}\text { S. viminalis } \\
\text { 'Bowles } \\
\text { Hybrid' }\end{array}$ & S. rossica \\
\hline $\begin{array}{l}\text { NWC } 674 \\
\text { S. viminalis } \\
\text { 'English } \\
\text { Rod' đે }\end{array}$ & - & - & - & - & - & - \\
\hline $\begin{array}{c}\text { NWC } 844 \\
\text { S. purpurea } \\
\text { 'Uralensis' } \\
\text { q }\end{array}$ & - & - & & - & - & - \\
\hline
\end{tabular}


Table S2: Survival and performance of plants by genotype from the time of shipping to after the first winter in the field.

\begin{tabular}{ccccccccc}
\hline Clone & Shipped & $\begin{array}{c}\text { Survived } \\
\text { Shipping }\end{array}$ & $\begin{array}{c}\text { Lost } \\
\text { Leaves }\end{array}$ & $\begin{array}{c}\text { Survived } \\
\text { Transfer }\end{array}$ & $\begin{array}{c}\text { Survived } \\
\text { Transplant }\end{array}$ & $\begin{array}{c}\text { Survived } \\
\text { Winter }\end{array}$ & \multicolumn{2}{c}{$\begin{array}{c}\text { Shoot } \\
\text { Damage }\end{array}$} \\
\hline RR09411 & 5 & 4 & 4 & 4 & 4 & 3 & 3 & 0 \\
\hline RR09491 & 10 & 10 & 9 & 9 & 9 & 8 & 2 & 6 \\
\hline RR09586 & 10 & 10 & 7 & 6 & 6 & 5 & 3 & 2 \\
\hline RR09593 & 10 & 10 & 2 & 9 & 9 & 8 & 4 & 4 \\
\hline RR08222 & 1 & 1 & 1 & 1 & 1 & 1 & 1 & 0 \\
\hline RR08267 & 6 & 6 & 6 & 3 & 3 & 3 & 3 & 0 \\
\hline RR08402 & 7 & 7 & 3 & 7 & 7 & 7 & 2 & 5 \\
\hline Total & $\mathbf{4 9}$ & $\mathbf{4 8}$ & $\mathbf{3 2}$ & $\mathbf{3 9}$ & $\mathbf{3 9}$ & $\mathbf{3 5}$ & $\mathbf{1 8}$ & $\mathbf{1 7}$ \\
\hline
\end{tabular}


Figure S1: Traditional Rothamsted Research willow breeding scheme (A) showing a typical 10-year time-span from initial crosses to first stages of varietal commercialisation compared to the shorter scheme using tissue culture and micro-propagation technologies (B).

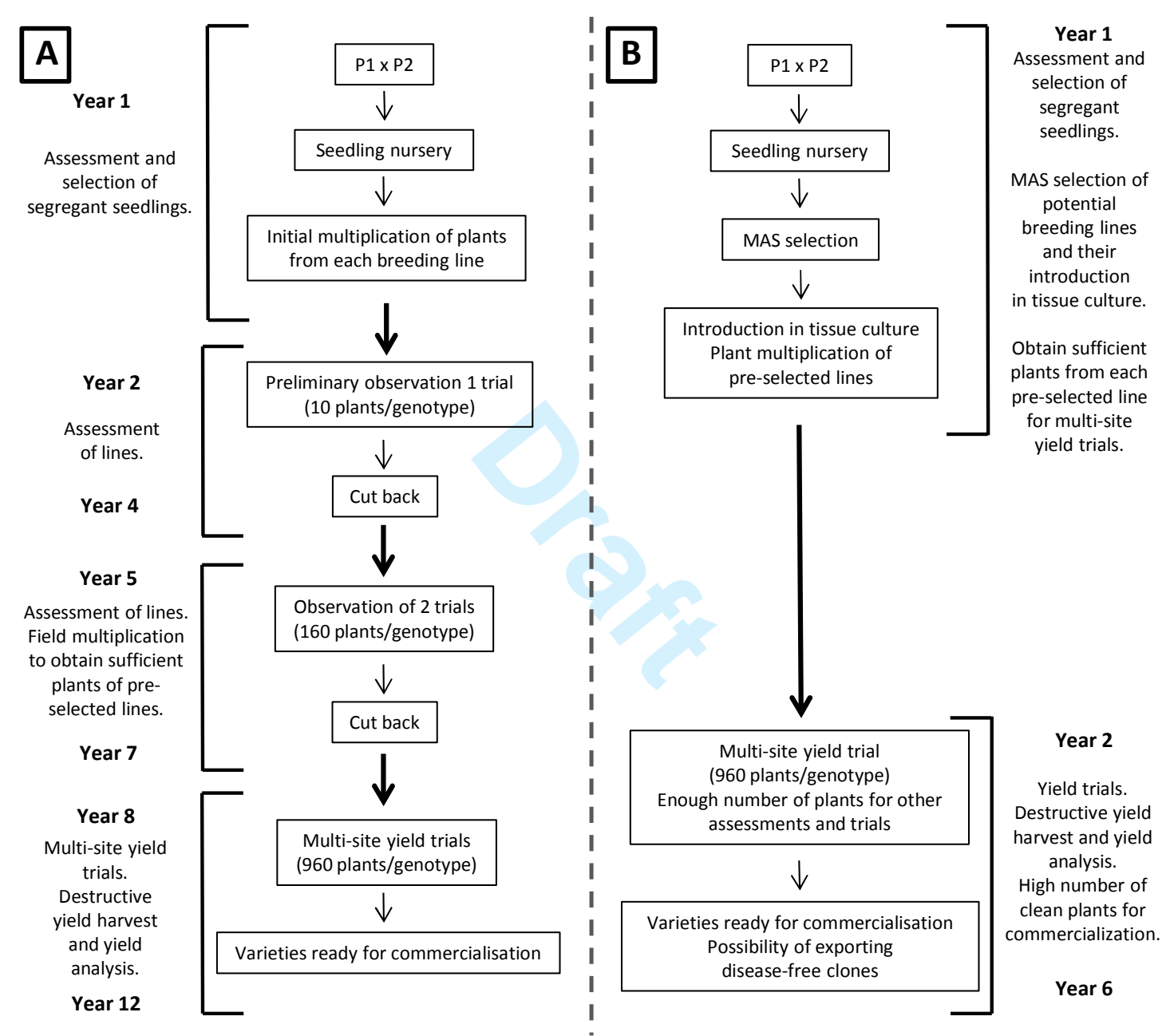


Figure S2: Shoot length (left axis) and rooting index (right axis) from bud-cultured plants of 10 different genotypes growing for 1, 2.5 and 4 months in regeneration medium. The rooting index (0-3) was calculated as the mean number of primary roots per plant after 4 months growth: $0=$ no roots, $1=1-5$ roots, $2=5-10$ roots and $3=$ more than 10 roots. Data represents means $\pm \mathrm{SE}$.

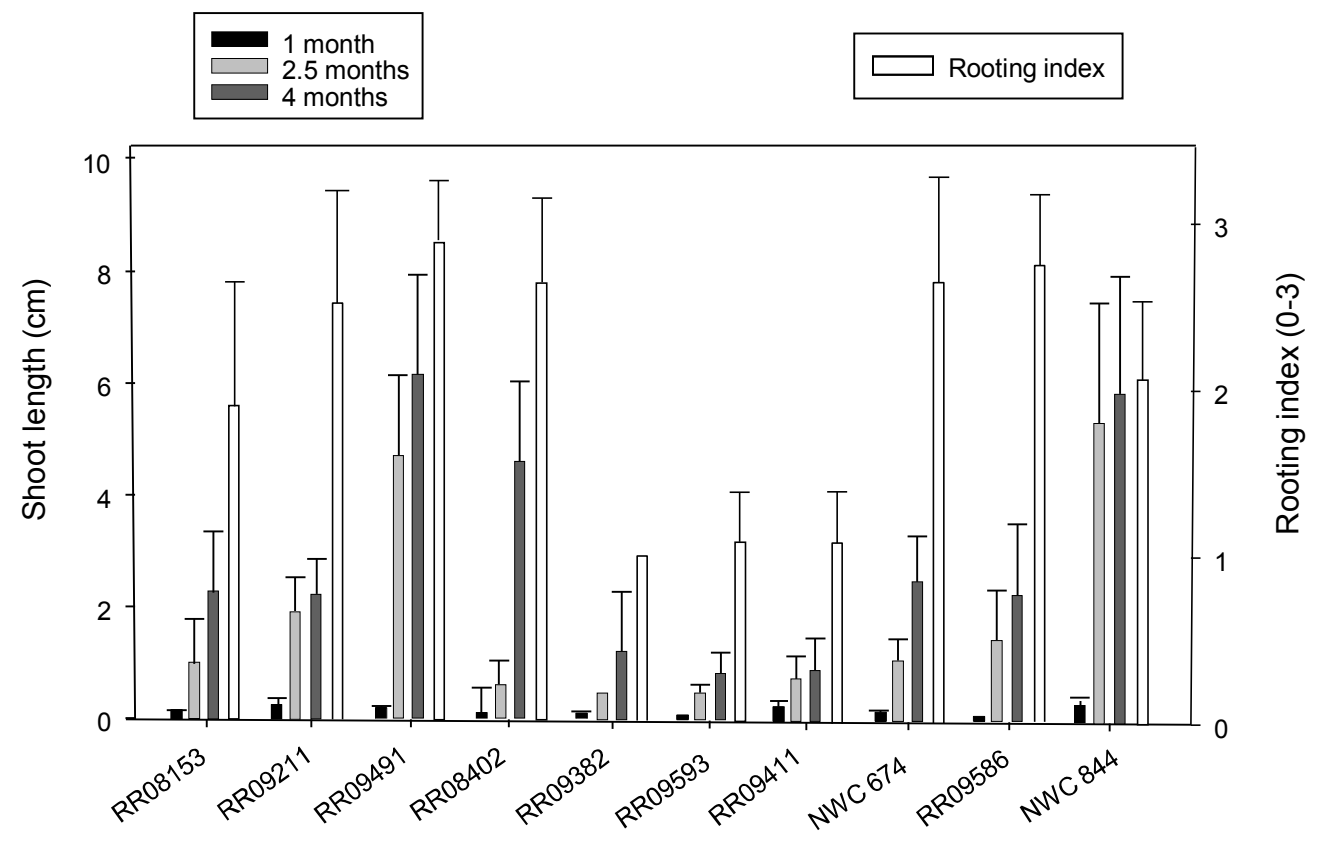

